
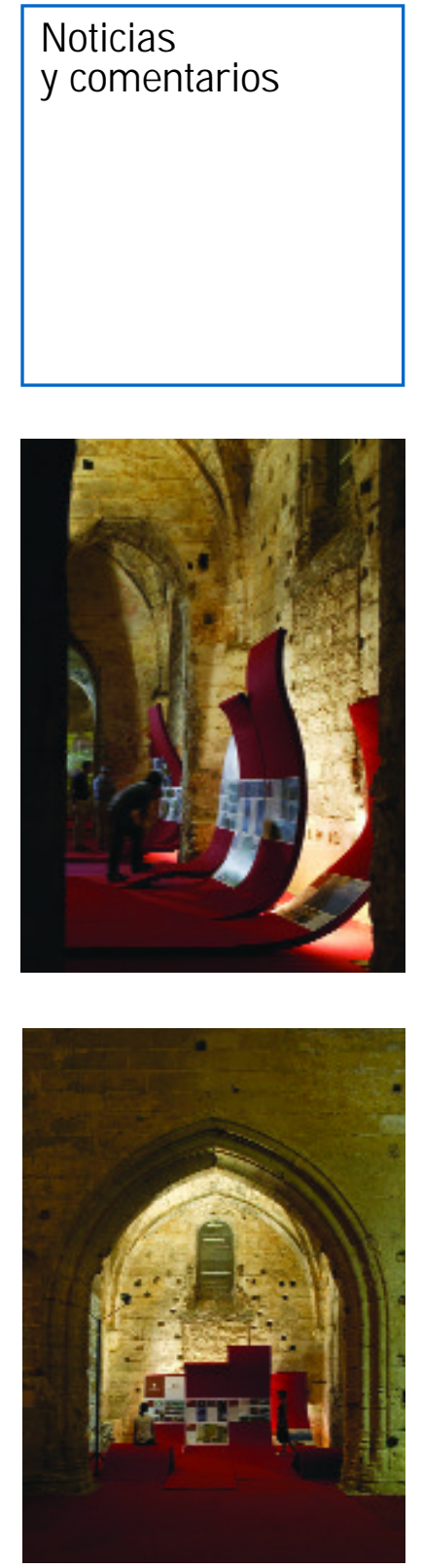

Montaje de la exposición

\title{
Simbiosis entre arquitectura y naturaleza en el nuevo diseño urbanístico de las ciudades
}

El marco de la sostenibilidad envuelve hoy prácticamente todas las facetas de la actividad humana, tras convertirse en una positiva obsesión de final de siglo. Se trata de una preocupación habitual en la historia del urbanismo. Vitrubio aportaba a aquellos que tenían en sus manos el diseño de nuevos asentamientos humanos recomendaciones en torno a cuestiones de emplazamiento, orientación, iluminación natural, etc. En el industrializado siglo XIX, los graves problemas de insalubridad urbana condujeron a un desarrollo de la tendencia higienista: Howard, Owen, las City Beautiful... Ya en el siglo XX, el Movimiento Moderno, desde su radical defensa del papel social de la arquitectura y el urbanismo, concebía las zonas verdes como una de las imprescindibles funciones que debía proporcionar la ciudad para el bienestar de sus habitantes.

Todos estos planteamientos entendían sin embargo a la naturaleza como un bien protegido pero susceptible de apropiación por el hombre y utilizado por sus efectos para la salud física y mental. Se carecía de una reflexión sobre el agotamiento de los recursos, algo que llegaría en los años cincuenta, con los inicios serios de la investigación sobre fuentes energéticas. Desde entonces se han alternado olas de conciencia ambiental (normalmente unidas a crisis de confianza), apagadas a golpes de desarrollismo.

Hoy parece que hemos alcanzado un cierto grado de madurez en este sentido y, pese a encontrarnos en un periodo que no se caracteriza especialmente por su falta de optimismo, en el que se nos vende una sociedad en la que todo "va bien", la conciencia ambiental ha calado hondo en todos los niveles.

En el urbanismo actual esta sensibilidad se traduce en la necesidad de estimular un nuevo acercamiento entre ciudad y naturaleza, entre el paisaje del medio y el paisaje del hombre, favorecido por el paso de una generación obsesionada por la relación entre arquitectura y ciudad a otra más interesada por un nuevo contrato con la naturaleza.

En este marco se encuadró la exposición de la $3^{\mathrm{a}}$ Bienal Europea de Paisaje de Barcelona, cuyo sugerente título "Sólo con naturaleza" indicaba claramente la voluntad de transmitir que el paisaje, seguramente, es un prisma actual y sofisticado para reinventar nuestra relación con la naturaleza. La muestra distinguía los mejores proyectos de paisaje realizados en Europa durante 1998-2002; de los casi 500 proyectos presentados al premio, se reunieron 311 obras, organizadas morfológicamente en tres grupos: fuerzas, soportes y articulaciones.
Entre ellas, la muestra destaca las 14 obras finalistas que optaron al 3r Premio Europeo de Paisaje Rosa Barba, finalmente compartido por el Jardín Botánico de Burdeos y la intervención "Reconsiderando una Montaña", en el Cantón Suizo de Ticino. Una obra andaluza, el Sendero del Pinar de la Algaida, en la Bahía de Cádiz, recibió el Premio de la Opinión otorgado por el público participante en la Bienal.

La itinerancia de la Bienal por Andalucia, realizada en virtud de un convenio de colaboración entre la Dirección General de Ordenación del Territorio y Urbanismo de la Junta de Andalucía y el Colegio de Arquitectos de Cádiz, ha contado con un montaje propio a cargo de Cristina López Lago González y María Llerena Iñesta.

El montaje expositivo andaluz intenta contribuir a la pérdida de límites entre el mundo exterior e interior de la arquitectura, en una época en que la sociedad en general y la arquitectura en particular exploran nuevas relaciones con la naturaleza. Para ello se plantea como estrategia de presentación la proyección sobre los ancianos muros del edificio de imágenes del mundo exterior.

Arrancó en julio del 2004, en la inconclusa Iglesia gótica del Monasterio de la Victoria de El Puerto de Santa María. Este antiguo monasterio de mínimos franciscano posee una historia llena de altibajos que refleja a la perfección los avatares del Patrimonio Histórico en nuestro país. El tiempo se encargó de transformar en maldito su origen divino y hoy probablemente todos lo conozcan más por la etapa más negra de su historia, cuando acogió en su interior el tristemente famoso Penal de El Puerto de Santa María.

Hoy las condiciones han cambiado, como bien nos dijera Secchi, y el antiguo penal vuelve a renacer en la vida pública con actuaciones culturales que borren su pasado más reciente. En este marco, la muestra supuso una especial contribución a la última (de momento) transformación del edificio.

La intervención creó un renovado mundo interior, transformando la nave de su iglesia en un nuevo paisaje artificial. Una estrategia válida igualmente para los sucesivos contenedores que la han acogido: el Colegio de Arquitectos de Almería, las naves del Puerto de Huelva o la Iglesia del Convento de Nuestra Señora de los Reyes de Sevilla.

Ramón Pico

Arquitecto. Profesor Asociado ETSA Sevilla 